\title{
Factor Affecting of BIM Technique in the Construction Firms in Iraq
}

\author{
Hussein M. Hamada ${ }^{1, *}$, Ahmad Haron ${ }^{1}$, Zahrizan Zakiria ${ }^{1}$, and Ali M. Humada ${ }^{2}$ \\ ${ }^{1}$ Faculty of Civil Engineering \& Earth Resources, University Malaysia Pahang, 26300 Pekan, Pahang, \\ Malaysia \\ ${ }^{2}$ Electricity Production Directorate of Salahaldeen, Ministry of Electricity, 34007, Baiji, \\ Iraq
}

\begin{abstract}
The construction industry in Iraq became much more difficult than before because of complexities in the diagrams and documentations in the construction projects. Building information modeling (BIM) started to appear with entry the foreign companies to build the large projects in Iraq. It is a bode well technique for the construction industry, it has many benefits in all project phases from planning and scheduling to operation and demolition phase. This paper concentrated on the implementation of BIM technology and identify the benefits desired and challenges that reduce adoption this technique in the Iraqi construction industry. A qualitative approach has been used to collect data from two experts in the construction field in Iraq to show the factors affected on using BIM in the Iraqi construction firms. The results indicate to a rare implementation of BIM technology among construction professionals in Iraq. The study recommended encouraging the investment in the Iraqi construction markets to share the knowledge and experiences related to BIM technology between the construction professionals.
\end{abstract}

\section{Introduction}

The construction industry in Iraq is still suffering from a lack of experts and competent professionals in the use of modern technology in the construction projects. Therefore, adversely effect on the progress of work in terms of delays in the completion of construction and increased construction costs. Most of the projects in Iraq are still based on the traditional methods in design and planning of projects such as using of 2D graphics and adoption of the critical path method (CPM) to calculate the time needed to complete the projects. Although these methods have been used for many years in the construction projects in the previous years, but it cannot be used in the large and complex projects. Therefore, should adoption of modern techniques, such as BIM technology for being less prone to error in the design and implementation by engineers, and have many benefits that no other. For example, when conduct modifying the properties of any element in the

\footnotetext{
* Corresponding author: enghu76@gmail.com
} 
construction such as windows, doors or walls, the amendment will appear automatically on all levels in addition to the adjustment in the bill of quantities. The National Building Information Modeling Standards (NBIMS) committee in the USA defines the BIM technology as, a digital representation of physical and functional characteristics of a facility [1-3]. BIM technique is a resource for information required by stakeholders in the construction. projects in order to simplify and facilitate sharing information during the life cycle of the project from planning to demolition phase [3].

\section{Problem statement}

The complexities and difficulties in interpretation of diagrams and schedules created by the traditional methods such as $2 \mathrm{D}$, and critical path method. These methods lead to errors and conflicts in the implementation of project tasks. Thus, using the traditional methods will lead to increase time and cost of projects, in addition to the effect on the quality of final product. Adoption of new technology in the construction companies has required the knowledge about benefits desired from this technology. Therefore, the aim of this paper is to find out the challenges and benefits of implementation the BIM technique within construction firms in Iraq.

\section{Literature review}

\subsection{Benefits of BIM technology}

There are many benefits result from implementation of BIM technology in the construction projects. The most important advantages of BIM technology identified by previous studies such as [4] conducted a survey about the benefits and barriers of BIM technology to the construction companies, more than 400 people participated in this questionnaire survey ,including the contractor, sub-contractor, and project managers. The result of the study proved that most of applications BIM users were to visualization, clash detection, and building design as shown in Fig. 1. Overall, BIM technology assists the project managers and planners to control the cost and time of construction project, in addition, to improving the quality of project model in early phases of project lifetime $[5,6]$. Thus, all these advantages will contribute to raising the level of construction productivity [5, 7]. However, many case studies conducted in various projects proved the advantages and benefits of BIM, for instance, [8] implement a case study and said that can be get saving money and time of project if used the BIM technology in the process through minimizing of rework the design documents. While, [9] said that advantages of BIM application by appearing the benefits resulting from the return on investment (ROI) when implementation of BIM in the construction projects.

\subsection{Challenges of 4D/BIM technology}

There are many challenges and barriers to adoption of BIM technology in the construction firms. The most common challenges to adopting BIM technology within construction firms identified by some researchers such as [4, 10-21]. One of the biggest problems that counter of construction firms, is the difficulty in correct visualize to the construction planning in workspaces through creating complex schedules and difficult in the interpretation [15]. The absence of agreed visualization standards which represent the building components and 
elements, activities, and resources. Information visualization to 4D data representation as one of the obstacles to implementation the BIM technique in the construction projects [22].

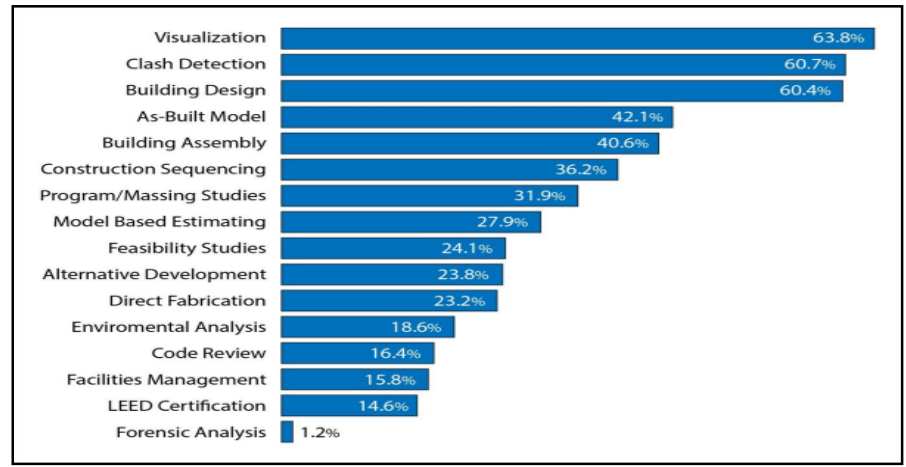

Fig. 1. Benefits of BIM in ranking [4]

\subsection{BIM and Iraqi construction industry}

Construction sector in Iraq is an important sector by contributing in the providing the houses, hotels, airports, railways and highways in Iraq. Therefore, the construction industry would affect the economy directly. In the last years, the Iraqi construction markets witnessed entry many of construction companies in order to build many projects inside of Iraq. The foreign companies with local companies started to implement the projects by using the BIM technique in their projects. Iraqi construction industry does not have more knowledge and skills to adopt BIM technology in short time for many causes, such as lack of experts in the BIM technology, lack of skills and knowledge for stakeholders involved in the projects, in addition to the cost of software and hardware, and training on it. In a recent survey by [23] proved that $92 \%$ of site engineers in the Iraqi companies do not have a professional certificates means that, do not have adequate knowledge and experience in the management of construction projects.

\section{Methodology}

The method of data collection for this study adopted a qualitative approach, which requires understanding deeply of a problem [24]. The qualitative approach also assist the researcher in finding out thinking of the respondents and what are their answers that effect on the results of research? The respondents in the research have been selected based on the experience in the construction industry and applying the BIM technique in the construction projects as shown in Table 1. All the interview sessions recorded and transcribed after taking approval from participants in the survey. The interview questions open ended were included the objectives following: 1) to find out the current status of BIM within Iraqi construction industry, 2) to collect the projects successful by using BIM technology, 3) to identify the benefits and challenges which lead to the successful projects. The content analysis method has been adopted to find out and validate the results obtained from the interview sessions. After that, the results has been discussed by comparing with the previous studies to find out the similarities among them as in Fig. 2.

Each the respondents R1 and R2, have an experience in the BIM and 4D modeling. In addition, they have high positions in their companies as can be seen in Table 1. 
Table 1. Profile of respondents and their experience.

\begin{tabular}{|c|c|c|c|}
\hline $\begin{array}{c}\text { Respondent } \\
\text { name }\end{array}$ & Designation & $\begin{array}{c}\text { Experience in } \\
\text { construction }\end{array}$ & Experience in BIM \\
\hline $\mathrm{A}$ & Senior management & More than 20 years & More than 6 years \\
\hline $\mathrm{B}$ & Project manager & More than 20 years & More than 8 years \\
\hline
\end{tabular}

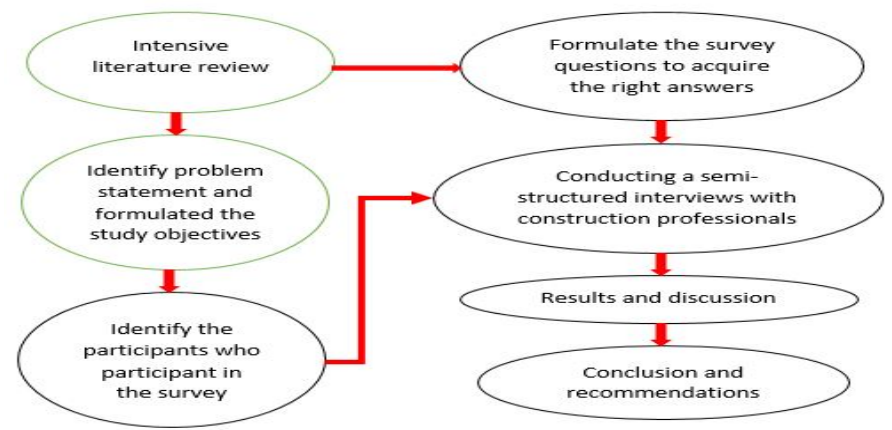

Fig. 2. Research method to data collection.

\section{Results and discussion}

This chapter will discuss the results obtained from the respondents in the interview sessions, and contains four parts.

\subsection{Basra main stadium (by 360 architecture)}

There are a number of construction projects implemented by using BIM technique in Iraq, which displays successful implementation and utilization of integrated drawings with schedules in a multidisciplinary environment, such as Basra Main Stadium 65,000 seats and Al Minaa Stadium 30,000 seats [25] located in Basra city in the southern of Iraq. The fabrication process designed by 360 Architecture, Kansas City. The fabrication process consists of 100-foot long glass fiber reinforced plastic (GFRP) as can be seen in Fig. 3 a.

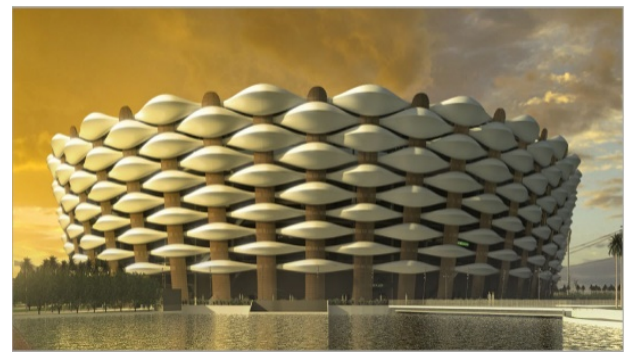

a. Basra main stadium

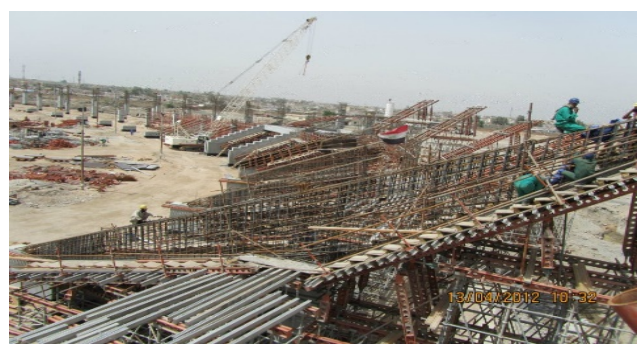

b. Al Minaa soccer stadium

Fig. 3. (a and b): Basra stadiums by (by 360 architecture)

The construction of Basra sports city was started on 15 July 2009 and completed on 12 October 2013. The city is being funded by the government of Iraq with a budget spending 
of $\$ 550$ million, contributed to contain the main stadium with the capacity of 65,000 people.

Table 2. Details of sport city in Basra

\begin{tabular}{|c|l|l|}
\hline No & Items & Details \\
\hline 1 & Owner & Ministry of Youth and Sport in Iraq \\
\hline 2 & Contractor & Abdullah Al-Jiburi Contracting Company \\
\hline 3 & Consultant & 360 Architecture, Kansas City \\
\hline 4 & Site area & 2.5 million-square-foot \\
\hline 5 & Contract Period & 32 months \\
\hline 6 & Start of construction & July 2009 \\
\hline 7 & Completed of structure & October 2013 \\
\hline
\end{tabular}

\subsection{Al Minaa Stadium project}

The construction of Al Minaa stadium as shown in Fig. 3b, was started on 2011 and completed on 2013. The stadium also funded by the Iraqi government with a budget $\$ 86$ million, to build the stadium with capacity 30000 people. The contractor was Anwar Soura General Contracting Company, while the consultant and the design team was 360 Architecture in American. The details of Al Minaa stadium as in Table 3 below.

Table 3. Details of Al Minaa stadium in Basra city

\begin{tabular}{|l|l|l|}
\hline No & Items & Details \\
\hline 1 & Owner & Ministry of Youth and Sport in Iraq \\
\hline 2 & Contractor & Anwar Soura General Contracting Company \\
\hline 3 & Consultant & American 360 Architecture \\
\hline 4 & Contract Period & 24 months \\
\hline 6 & Start of construction & 2011 \\
\hline 7 & Completed of structure & 2013 \\
\hline
\end{tabular}

The owner of the project is the Ministry of Youth and Sport in Iraq, while the main contractor was Anwar Soura General Contracting Company. R1 represents one of the management of the project, $\mathrm{R} 2$ represent one of the contractor staff in the project.

\subsection{Benefits of 4D/BIM in the projects}

Regarding the benefits of BIM to the project, R1 and R2 said that: Implementation BIM in the construction of sport city in Basra assist the design team on the following points:

i) To share information in the BIM model among the architects and engineers throughout the design phase, in order to meet the design requirements.

ii) Checking logistical and economic constraints a daily in addition to finding out the constructability issues and clashes.

iii) To minimize the time required to fabrication the panels needed to the project by 18 months, therefore adoption of BIM applications to take the design from five models differently.

iv) To achievement the construction and fabrication process of the stadium's skin components at the same time planned. 
v) To enable and simplify the smooth interaction among the fabricator and design team, whereas, the project team chose application a digital information in the project [25].

vi) Using BIM software would allow the architects to control the large and complex surface geometry of the project panels.

vii) To do a platform as open communication among all the specialists in the project with the central model.

viii) BIM has the ability to see every detail on a construction project including the wires, the pipes, the columns, beams and collect they in the 3D model before actually starting the construction.

\subsection{Challenges of 4D/BIM in the projects}

As mentioned by the R1 and R2 in the interview sessions, implementation of BIM in the construction projects faced many challenges, first of all:

i) The high cost to purchase the sophisticated software and hardware related BIM technology such as Tekla and Revit.

ii) Training on the BIM equipment and provide the cost and time needed to acquire the necessary skill and knowledge in this regard. Therefore, most of the BIM companies in Iraq is an international company, thus, they have the ability to implement BIM in their projects.

iii) Compatibility problems between the BIM software, particularly with regard to the structural safety of the construction because of adoption more than an approach in the design the various facilities of the project.

\section{Conclusion and recommendations}

BIM technology has many benefits, on the other hand, has many challenges as shown in the implementation of sports city in Basra and Al Minaa stadium. All these projects funded by the Iraqi government, and came to enhance the quality of the project by using BIM modeling in the construction industry. In Basra city has been implemented two projects by using BIM technology. All of them designed by the American 360 Architecture. The projects illustrate the benefits and challenges due to use the BIM. some of the benefits identified through the interview sessions with the respondents, such as minimize the time and cost required to the project and getting on the better model of the project, besides clash detection between the project component in an early age of project life. All these factors led to limit the rework for the project tasks. Thus cancel additional time and cost of the project. Many projects have been implemented by application of BIM technology such as an educational al-Najaf hospital in the al-Najaf city, also funded by the Iraqi government. Therefore, the study recommends that the Iraqi government should seek to engage the foreign companies with Iraqi companies in implementing more projects BIM within Iraqi construction industry in order to share the knowledge and experience among construction professionals.

\section{References}

[1] H. Penttilä, Describing the changes in architectural information technology to understand design complexity and free-form architectural expression, ITcon, 11 (Special Issue), 395-408 (2006) 
[2] B. Ernstrom, D. Hanson, D. Hill, J.J. Clark, M.K. Holder, D.N. Turner and T.W. Barton, The contractors' guide to BIM, Associated General Contractors of America, Arlington, VA (2006)

[3] C. Eastman, C.M. Eastman, P. Teicholz and R. Sacks, BIM handbook: A guide to building information modeling for owners, managers, designers, engineers and contractors, John Wiley \& Sons, New Jersey, Canada (2008)

[4] B. Becerik-Gerber and S. Rice, The perceived value of building information modeling in the US building industry, J. of Information Technology in Construction, 15, 185201, (2010)

[5] S. Azhar, A. Nadeem, J. Mok and B. Leung, Building information modeling (BIM): A new paradigm for visual interactive modeling and simulation for construction projects, Proc. First International Conf. on Construction in Developing Countries, Karachi, Pakistan (2008)

[6] M. Fischer and J. Kunz, The scope and role of information technology in construction, Proceedings-Japan Society of Civil Engineers, Centre for Integrated Facility Engineering, 1-32 (2004)

[7] P.E. Love, D.J. Edwards, S. Han and Y.M. Goh, Design error reduction: toward the effective utilization of building information modeling, Research in Engineering Design, 22, 173-187 (2011)

[8] G. Aranda-Mena, J. Crawford, A. Chevez and T. Froese, Building information modelling demystified: Does it make business sense to adopt BIM?, Int. J. of Managing Projects in Business, 2, 419-434 (2009)

[9] S. Jones, SmartMarket report, building information modeling transforming design and construction to achieve greater industry productivity, McGraw-Hill Professional, Bedford, UK (2009)

[10] S.M. Ahmed, H.H. Emam and P. Farrell, Barriers to BIM/4D implementation in Qatar, The 1st International Conf. of CIB Middle East \& North Africa Conf., Abu Dhabi, UAE, 533-547 (2014)

[11]Y.H. Ahn, Y.H. Kwak and S.J. Suk, Contractors' transformation strategies for adopting building information modelling, Journal of Management in Engineering, 32(1), 05015005, (2015).

[12]M. Ali and J. Mohd Noor, Acceptability of Malaysian construction practitioners in adopting 4D, First International Conf. on Islamic Built Environment, Bandung, Malaysia (2012)

[13] S. Azhar, M. Khalfan and T. Maqsood, Building information modelling (BIM): Now and beyond, Construction Economics and Building, 12, 15-28 (2015)

[14]D.M. Brito and E.A. Ferreira, Strategies for representation and analyses of 4D modeling applied to construction project management, Procedia Economics and Finance, 21, 374$382(2015)$

[15]F. Castronovo, S. Lee, D. Nikolic and J.I. Messner, Visualization in 4D construction management software: A review of standards and guidelines, Int. Conf. on Computing in Civil and Building Engineering, Computing in Civil and Building Engineering, 315322 (2014)

[16]N.N. Dawood and S. Sikka, Measuring the effectiveness of 4D planning as a valuable communication tool', in Messner, International Journal of Information Technology in Construction, 13, 620-636 (2008)

[17]I. Kaner, R. Sacks, W. Kassian and T. Quitt, Case studies of BIM adoption for precast concrete design by mid-sized structural engineering firms, ITcon, 13 (Special Issue), 303-323 (2008) 
[18]M. Kassem, T. Brogden and N. Dawood, BIM and 4D planning: A holistic study of the barriers and drivers to widespread adoption, J. of Construction Engineering and Project Management, 2, 1-10 (2012)

[19]I. Kiani, A.N. Sadeghifam, S.K. Ghomi and A.K.B. Marsono, Barriers to implementation of Building Information Modeling in scheduling and planning phase in Iran, Australian Journal of Basic and Applied Sciences, 9, 91-97 (2015)

[20] M. Mohamed Kassem and T. Brogden, BIM and 4D planning: An empirical study of the industry uptake and issues affecting their widespread use, Proceedings of the CIB W78 2012: 29th International Conf., Beirut, Lebanon (2012)

[21] M.H. Tsai, S.C. Kang, and S.H. Hsieh, A three-stage framework for introducing a 4D tool in large consulting firms, Advanced Engineering Informatics, 24, 476-489 (2010)

[22] R. Mazza, Introduction to information visualization, Springer Science \& Business Media, London, United Kingdom (2009)

[23]F.M.S. Al-Zwainy, I.A. Mohammed and S.H. Raheem, Investigation and assessment of the project management methodology in Iraqi construction sector, Int. J. of Applied Engineering Research, 11, 2494-2507 (2016)

[24] S. B. Merriam, Qualitative research and case study applications in education. Revised and expanded from, Jossey-Bass Publishers, San Francisco, USA (1998)

[25]J. Schumacher and R. K. Otani, Advanced computational modeling in multidisciplinary design, Proc., Structures Congress 2012: 20th Analysis and Computation Specialty Conf., ASCE, New York, 231-244 (2012) 